\title{
EFFECT OF WATER STRESS ON PHYSIOLOGICAL PARAMETERS OF BAMBARA GROUNDNUT (VIGNA SUBTERRANEA (L.) VERDC.) ACCESSIONS
}

\author{
Dorcas Ropo ABEJIDE ${ }^{1 *}$, Olamide Ahmed FALUSI ${ }^{2}$, Matthew Omoniyi ADEBOLA ${ }^{2}$, \\ Andrew Saba GANA ${ }^{3}$, Abdulhakeem ABUBAKAR ${ }^{2}$, Muhammad DANGANA ${ }^{2}$ \\ ${ }^{1}$ Department of Plant Science and Biotechnology, Kogi State University, Anyigba, \\ Kogi State - Nigeria \\ ${ }^{2}$ Department of Plant Biology, Federal University of Technology, Minna Niger State - Nigeria \\ ${ }^{3}$ Department of Crop Production, Federal University of Technology, Minna Niger State - Nigeria \\ ${ }^{*}$ Corresponding author. E-mail: doroapitan@yahoo.com
}

\begin{abstract}
In order to evaluate the effect of water stress on physiological parameters of bambara groundnut, twenty-eight accessions were evaluated at the Experimental garden of the Department of Biological Sciences, Federal University of Technology, Minna, Niger State Nigeria. They were subjected to two treatments, water stressed and non-water stressed. The accessions were sown in planting bags and arranged in a randomized complete block design with three replicates. Significant differences in all physiological parameters were observed between the bambara groundnut accessions in both the water stressed and the non-water stressed treatment. Relative water content, chlorophyll a, chlorophyll b and total chlorophyll content was higher in non-water stressed plants than water stressed plants, although relatively high water content, chlorophyll a, b and total chlorophyll contents were still observed in stressed plants. It was also observed that bambara groundnut accessions explored drought tolerant mechanisms by closing their stomata to reduce water loss.
\end{abstract}

Keywords: accessions, bambara groundnut, chlorophyll, drought, relative water content, water stress.

\section{Introduction}

Bambara Groundnut (Vigna subterranea (L.) Verdc.) - Family Fabaceae, is a legume plant native to Africa [ADU-DAPAAH \& SANGWAN, 2004]. It is the third most commonly eaten legume after Cowpea (Vigna unguiculata) and Peanuts (Arachis hypogea) and a major source of protein for resourced poor farmers in Nigeria [ABEJIDE \& al. 2017]. It is an annual crop grown for the purpose of its seeds which are produced in pods under the ground. Bambara groundnut exists as landraces, rather than cultivars, and consists of several genotypes resulting in their ability to tolerate different types of stress (both biotic and abiotic) in low input Agricultural Systems [LINNEMANN \& CRAUFURD, 1994]. Landraces have recognizable morphological features such as testa colour that can be used to identify them. The Landraces are named mostly based on the testa colour or the place where they are grown or collected [LACROIX \& al. 2003].

Rainfall is low and erratic in the semi-arid parts of Nigeria, where the production and consumption of bambara groundnut are well established [ABEJIDE \& al. 2018]. Consequently drought can be a limiting factor in the production of rainfed crops in these regions [AZAM-ALI \& al. 2001]. Limited evidence exists on the degree and mechanism of resistance of bambara groundnut to drought. MALHOTRA \& SAXENA (2002) observed differences in the response of two bambara groundnut landraces and attributed that to climatic conditions in the area of collection. In order to improve the yield and to fully Received: 6 March 2020 / Revised: 14 November 2020 / Accepted: 27 November 2020 
exploit the potential of bambara groundnut, a more thorough understanding of the mechanisms of its response to water stress is needed.

\section{Materials and methods}

\section{Source of seeds}

The seeds used for the study were collected from farmers in seven States in Northern Nigeria such as Niger, Kogi, Plateau, Kaduna, Nassarawa, Adamawa and Jigawa States. Some seeds were also collected from National Centre for Genetic Resources and Biotechnology (NACGRAB) Ibadan, Nigeria. The seeds were sown at the Department of Biological Sciences Experimental garden, Federal University of Technology Minna, Niger State. Minna is located between latitude $90^{\circ} 31^{\prime}$ and $90^{\circ} 45^{\prime}$ North and longitude $60^{\circ} 31^{\prime}$ and $60^{\circ} 45^{\prime}$ East of the equator. The area falls within the Southern Guinea savannah vegetation zone of Nigeria with an annual precipitation varying from 1,100-1,600 mm, mean temperature between $21{ }^{\circ} \mathrm{C}$ and $36.5{ }^{\circ} \mathrm{C}$ and relative humidity between 50 to $61 \%$ (The Nigerian Congress, 2007).

\section{Experimental design}

Bambara groundnut accessions were grown in two different treatments Non Water stressed (NST) and water stressed (ST) condition. Plants were rain fed and received water at least twice in a week throughout the experiment except for the stressed plants which were deprived of water for 14 days during the flowering stage by transferring plants to a shade house made of transparent polyvinyl ceiling. The accessions were grown in planting bags in a randomized complete block design with five replicates. Two seeds were sown per bag and the bags were given a spacing of $30 \times 30 \mathrm{~cm}$ (inter and intra row spacing) and later thinned to one at 2 weeks after planting. The following physiological parameters were determined after stress period both in the stressed plants and non-water stressed plants, relative water content, chlorophylls a, b, total chlorophyll content and stomata opening.

\section{Relative water content (RWC)}

RWC was determined following the method of VURAYAI \& al. (2011). Five leaf discs from leaves of three tagged plants per replication were cut using a cork borer (about $11 \mathrm{~mm}$ diameter). The leaf discs were placed in pre-weighed vials, sealed and reweighed to derive their fresh weight (FW) before being placed in petri dishes lined with two layers of germinating paper saturated with deionized water. This was sealed with tape to prevent evaporation and left overnight under a light source to allow discs to re-hydrate to their turgid weight (TW). Their dry weight (DW) was obtained after overnight drying at $80{ }^{\circ} \mathrm{C}$ for $48 \mathrm{~h}$. The leaf RWC was then measured and calculated according to TURNER \& BEGG (1981) as:

$$
\text { RWC }(\%)=[(F W-D W) /(T W-D W)] \times 100 \%
$$

\section{Stomata opening}

Three leaves of bambara groundnut from each treatment were harvested at about 9 a.m. in the morning. Nail polish was applied on the clean dry leaf and then celotape was placed on it. It was then allowed to dry and peeled off. Afterwards, the celotape with the peeled polish was mounted on a slide and then viewed with a microscope (x40-x100). 


\section{Leaf chlorophyll content}

Leaf disks of about $0.25 \mathrm{~g}$ were used for determination of actual leaf chlorophyll content by photometric methods as described by PORRA \& al. (1989). Chlorophyll was extracted from the leaf tissue using a buffered $80 \%$ aqueous acetone solution and absorbance was measured on the supernatant by a UV 160 IPC spectrophotometer. Chlorophyll content was expressed in Xg chl.g/Fwt, where Fwt denotes fresh weight. Chlorophyll a, b and total chlorophyll was determined using the below formulas:

Chlorophyll $\mathrm{a}=10.3 \mathrm{D}_{663}-0.918 \mathrm{D}_{644}$

Chlorophyll $\mathrm{b}=19.7 \mathrm{D}_{644}-3.8 \mathrm{D}_{633}$

Total Chlorophyll $=6.4 \mathrm{Q}_{633}+18.8 \mathrm{D}_{644}$

Where $\mathrm{D}_{663}=$ Value of absorbance at wavelength 663

$\mathrm{D}_{644}=$ Value of absorbance at wavelength 644

$\mathrm{D}_{633}=$ Value of absorbance at wavelength 633

\section{Results}

\section{Relative water content}

There were significant differences observed in the relative water content of the bambara groundnut accessions in both stressed and non-stressed plants. The highest relative water content was observed in accession (NGB-01491) in both stressed and non-stressed plants $(72.73,75)$ and the least relative water content was observed in accession (NGRKG-02-C) in both water stressed and non-stressed plants $(42.36,48)$. It was observed that the bambara groundnut accessions were still able to maintain high relative water contents despite the water stress (Figure 1).

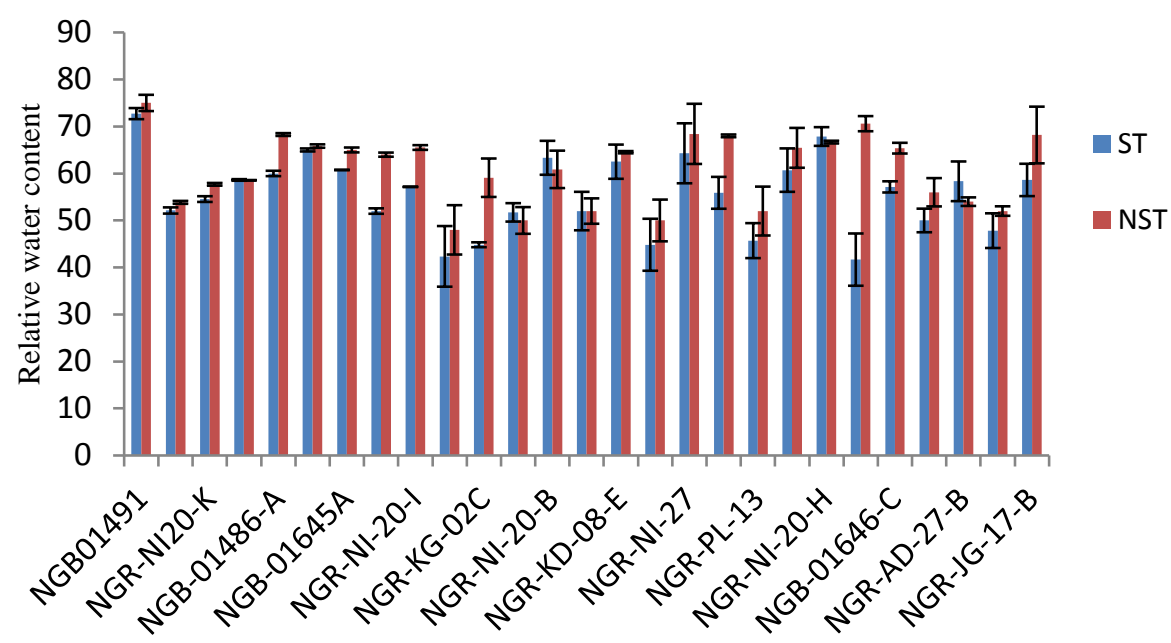

Bambara Groundnut accessions

Figure 1. Relative water content of Water stressed and Non-water stressed Bambara Groundnut accessions. 


\section{Chlorophyll content}

There were also significant differences observed in chlorophyll a, chlorophyll b and total chlorophyll content amongst the bambara groundnut accessions in both stressed (ST) and non-water stressed (NST) plants (Table 1). The highest chlorophyll a content in the stressed plants was observed in accession NGR-NI-25-A (10.90 g). It was not significantly different from accessions NGB-01645-A, NGR-NI-20-J, NGR-AD-27-B and NGR-JG-17-A but significantly different from all other accessions. The lowest was observed in accession NGR-NS-15 (4.23 g) and it was significantly different from all other accessions except NGR-NI-27, NGB-01493, NGR-NI-20B, NGR-PL-12, NGB-01496, NGR-NI-20H and NGB-01646-B. In the non-water stressed plants, the highest chlorophyll a content was observed in accession NGR-PL-12 (12.50 g) and it was not significantly different from accessions NGR-NI-27 and NGR-NI-20-J but significantly different from all other accessions, while the lowest was observed in accession NGR-NI-20-I (7.15 g) and it was not significantly different from accession NGR-KG-01 but significantly different from all other accessions.

The highest chlorophyll b content in the stressed plants was observed in accession NGB-01646-C (23.94 g) and the lowest in accession NGB-01493 (10.37 g) which was significantly different from all other accessions. In the non-stressed plants the highest chlorophyll b content was observed in accession NGR-AD-27-B (23.57 g). It was not significantly different from accessions NGR-JG-17-A, NGB-01486-A, NGR-KG-02-C but significantly different from all other accessions while the least chlorophyll b content was observed in accession NGR-NI-20-I (19.78 g) and it was significantly different from all other accessions.

The highest total chlorophyll content in the stressed plants was observed in accession NGB-01645-A (34.02 g) and the least in accession NGB-01493 (15.36 g) and it was significantly different from all other accessions except accession NGR-NS-15. In the non-stressed plants the highest total chlorophyll content was observed in accession NGRNI-20-H (37.41 g) and it was significantly different from all other accessions. The least total chlorophyll content was observed in accession NGR-NI-20-I (27.19 g) and it was significantly different from all other accessions. Chlorophyll a, b and total chlorophyll contents had higher values in the non-water stressed plants compared to the stressed plants for most of the accessions.

\section{Stomata opening}

The stomata opening of the bambara groundnut accessions in the non-water stressed plants were observed to be opened but in the stressed plants, the stomata opening were observed to be closed. Figure 2 is the stomata opening of bambara groundnut accession in the non-water stressed plants showing opened stomata, while figure 3 is the stomata opening of the bambara groundnut accession in the stressed plants showing closed stomata. 
Dorcas Ropo ABEJIDE \& al.

Table 1. Mean Values of Chlorophyll content measured in water stressed (ST) and non-water stressed (NST) conditions.

\begin{tabular}{|c|c|c|c|c|c|c|c|}
\hline \multirow{2}{*}{ S/No } & \multirow{2}{*}{ Accessions } & \multicolumn{2}{|c|}{ Chlorophyll a } & \multicolumn{2}{|c|}{ Chlorophyll b } & \multicolumn{2}{|c|}{ Total Chlorophyll } \\
\hline & & ST & NST & ST & NST & ST & NST \\
\hline 1 & NGB01491 & $8.35 \pm 0.00^{\mathrm{b}}$ & $11.98 \pm 0.01^{\mathrm{b}}$ & $21.31 \pm 0.04^{\mathrm{b}}$ & $22.64 \pm 0.01^{\mathrm{b}}$ & $29.38 \pm 0.04^{b}$ & $35.58 \pm 0.01^{\mathrm{bc}}$ \\
\hline 2 & NGB-01493 & $6.58 \pm 0.02^{\mathrm{ab}}$ & $9.53 \pm 0.00^{\mathrm{b}}$ & $10.37 \pm 0.03^{\mathrm{a}}$ & $22.61 \pm 0.00^{\mathrm{b}}$ & $15.36 \pm 0.00^{\mathrm{a}}$ & $33.14 \pm 0.00^{\mathrm{b}}$ \\
\hline 3 & NGR-NI20-K & $7.44 \pm 0.00^{\mathrm{b}}$ & $11.45 \pm 0.01^{\mathrm{b}}$ & $20.37 \pm 0.03^{b}$ & $22.84 \pm 0.02^{\mathrm{b}}$ & $28.14 \pm 0.03^{b}$ & $35.03 \pm 0.03^{b c}$ \\
\hline 4 & NGB-01311 & $7.96 \pm 0.01^{\mathrm{b}}$ & $11.49 \pm 0.00^{\mathrm{b}}$ & $20.57 \pm 0.03^{b}$ & $22.99 \pm 0.13^{\mathrm{b}}$ & $28.54 \pm 0.01^{b}$ & $34.88 \pm 0.01^{b c}$ \\
\hline 5 & NGB-01486-A & $9.75 \pm 0.01^{b}$ & $11.63 \pm 0.17^{b}$ & $22.29 \pm 0.04^{c}$ & $23.30 \pm 0.01^{\mathrm{c}}$ & $32.22 \pm 0.03^{b c}$ & $35.17 \pm 0.02^{\mathrm{bc}}$ \\
\hline 6 & NGR-NI-23-C & $9.45 \pm 0.02^{\mathrm{b}}$ & $11.93 \pm 0.01^{\mathrm{b}}$ & $22.43 \pm 0.04^{c}$ & $22.90 \pm 0.01^{\mathrm{b}}$ & $31.27 \pm 0.03^{b}$ & $35.08 \pm 0.02^{\mathrm{bc}}$ \\
\hline 7 & NGB-01645A & $10.19 \pm 1.09^{c}$ & $10.98 \pm 0.02^{\mathrm{b}}$ & $22.92 \pm 0.02^{\mathrm{c}}$ & $22.98 \pm 0.01^{\mathrm{b}}$ & $34.02 \pm 0.00^{c}$ & $34.49 \pm 0.02^{\mathrm{bc}}$ \\
\hline 8 & NGR-NI-18 & $7.65 \pm 0.00^{\mathrm{b}}$ & $9.76 \pm 0.00^{\mathrm{b}}$ & $21.39 \pm 0.03^{\mathrm{bc}}$ & $21.89 \pm 0.01^{\mathrm{b}}$ & $29.60 \pm 0.02^{\mathrm{b}}$ & $33.12 \pm 0.02^{b}$ \\
\hline 9 & NGR-NI-20-I & $7.33 \pm 0.00^{\mathrm{b}}$ & $7.15 \pm 0.00^{\mathrm{a}}$ & $20.77 \pm 0.01^{\mathrm{b}}$ & $19.78 \pm 0.00^{\mathrm{a}}$ & $28.22 \pm 0.02^{b}$ & $27.19 \pm 0.00^{\mathrm{a}}$ \\
\hline 10 & NGR-NI-22 & $7.29 \pm 0.01^{b}$ & $10.81 \pm 0.00^{\mathrm{b}}$ & $20.54 \pm 0.03^{b}$ & $22.62 \pm 0.01^{\mathrm{b}}$ & $27.43 \pm 0.02^{\mathrm{b}}$ & $34.00 \pm 0.01^{\mathrm{bc}}$ \\
\hline 11 & NGR-KG-02C & $7.75 \pm 0.01^{b}$ & $10.65 \pm 0 .^{b}$ & $21.62 \pm 0.02^{\mathrm{b}}$ & $23.50 \pm 0.04^{c}$ & $28.75 \pm 0.02^{b}$ & $34.50 \pm 0.05^{\mathrm{bc}}$ \\
\hline 12 & NGR-KG-01 & $9.45 \pm 0.03^{b}$ & $8.97 \pm 0.02^{\mathrm{a}}$ & $22.90 \pm 0.05^{\mathrm{bc}}$ & $21.97 \pm 0.15^{b}$ & $32.13 \pm 0.06^{\mathrm{bc}}$ & $32.16 \pm 0.03^{b}$ \\
\hline 13 & NGR-NI-20-B & $6.41 \pm 0.01^{\mathrm{ab}}$ & $9.96 \pm 0.01^{\mathrm{ab}}$ & $18.67 \pm 0.02^{\mathrm{b}}$ & $22.43 \pm 0.02^{\mathrm{b}}$ & $25.03 \pm 0.02^{\mathrm{b}}$ & $33.31 \pm 0.04^{\mathrm{b}}$ \\
\hline 14 & NGR-PL-12 & $6.98 \pm 0.01^{\mathrm{ab}}$ & $12.50 \pm 0.00^{c}$ & $20.19 \pm 0.02^{\mathrm{b}}$ & $22.65 \pm 0.07^{b}$ & $27.54 \pm 0.03^{b}$ & $35.64 \pm 0.04^{b c}$ \\
\hline 15 & NGR-KD-08-E & $7.09 \pm 0.07^{b}$ & $10.70 \pm 0.00^{\mathrm{b}}$ & $20.15 \pm 0.01^{\mathrm{b}}$ & $22.71 \pm 0.03^{b}$ & $27.53 \pm 0.00^{\mathrm{b}}$ & $33.95 \pm 0.04^{b}$ \\
\hline 16 & NGB-01496 & $6.35 \pm 0.01^{\mathrm{ab}}$ & $11.36 \pm 0.01^{\mathrm{b}}$ & $19.36 \pm 0.40^{\mathrm{b}}$ & $22.88 \pm 0.03^{b}$ & $25.18 \pm 0.00^{b}$ & $34.32 \pm 0.02^{b c}$ \\
\hline
\end{tabular}


EFFECT OF WATER STRESS ON PHYSIOLOGICAL PARAMETERS OF BAMBARA...

\begin{tabular}{|c|c|c|c|c|c|c|c|}
\hline 17 & NGR-NI-27 & $5.06 \pm 0.00^{\mathrm{a}}$ & $12.07 \pm 0.02^{\mathrm{c}}$ & $17.19 \pm 0.06^{\mathrm{b}}$ & $22.65 \pm 0.01^{b}$ & $22.94 \pm 0.07^{b}$ & $35.41 \pm 0.01^{\mathrm{bc}}$ \\
\hline 18 & NGR-NI-25-A & $10.90 \pm 0.02^{\mathrm{c}}$ & $11.87 \pm 0.01^{b}$ & $22.67 \pm 0.01^{\mathrm{c}}$ & $22.77 \pm 0.02^{b}$ & $33.76 \pm 0.02^{b c}$ & $35.22 \pm 0.04^{\mathrm{bc}}$ \\
\hline 19 & NGR-PL-13 & $9.76 \pm 0.01^{\mathrm{b}}$ & $11.18 \pm 0.01^{\mathrm{b}}$ & $22.75 \pm 0.01^{\mathrm{c}}$ & $22.56 \pm 0.02^{b}$ & $33.37 \pm 0.01^{b c}$ & $34.40 \pm 0.03^{\mathrm{bc}}$ \\
\hline 20 & NGR-NS-15 & $4.23 \pm 0.00^{\mathrm{a}}$ & $11.55 \pm 0.01^{b}$ & $12.86 \pm 0.01^{\mathrm{ab}}$ & $22.81 \pm 0.01^{b}$ & $16.80 \pm 0.01^{\mathrm{a}}$ & $34.63 \pm 0.01^{\mathrm{bc}}$ \\
\hline 21 & NGR-NI-20-H & $6.77 \pm 0.00^{\mathrm{ab}}$ & $10.20 \pm 0.01^{\mathrm{b}}$ & $19.35 \pm 0.03^{b}$ & $21.12 \pm 0.18^{b}$ & $26.33 \pm 0.02^{\mathrm{b}}$ & $37.41 \pm 0.04^{\mathrm{c}}$ \\
\hline 22 & NGB-01646-B & $6.90 \pm 0.02^{\mathrm{ab}}$ & $11.25 \pm 0.02^{b}$ & $19.61 \pm 0.01^{\mathrm{b}}$ & $22.46 \pm 0.18^{\mathrm{b}}$ & $26.54 \pm 0.01^{\mathrm{b}}$ & $34.58 \pm 0.01^{\mathrm{bc}}$ \\
\hline 23 & NGB-01646-C & $9.15 \pm 0.01^{b}$ & $11.38 \pm 0.01^{b}$ & $23.94 \pm 0.01^{\mathrm{c}}$ & $22.56 \pm 0.03^{b}$ & $29.47 \pm 0.00^{\mathrm{bc}}$ & $34.80 \pm 0.05^{b c}$ \\
\hline 24 & NGR-NI-20-J & $10.06 \pm 0.00^{c}$ & $12.21 \pm 0.00^{c}$ & $22.34 \pm 0.03^{c}$ & $22.62 \pm 0.02^{b}$ & $32.67 \pm 0.03^{b c}$ & $35.64 \pm 0.01^{\mathrm{bc}}$ \\
\hline 25 & NGR-AD-27-B & $10.25 \pm 0.02^{\mathrm{c}}$ & $10.37 \pm 0.02^{b}$ & $22.98 \pm 0.03^{c}$ & $23.57 \pm 0.05^{c}$ & $33.70 \pm 0.26^{\mathrm{bc}}$ & $34.86 \pm 0.05^{\mathrm{bc}}$ \\
\hline 26 & NGR-JG-17-A & $10.08 \pm 0.01^{\mathrm{c}}$ & $10.73 \pm 0.00^{\mathrm{b}}$ & $22.48 \pm 0.01^{\mathrm{c}}$ & $23.06 \pm 0.00^{c}$ & $32.91 \pm 0.00^{\mathrm{bc}}$ & $34.12 \pm 0.01^{b c}$ \\
\hline 27 & NGR-JG-17-B & $7.05 \pm 0.00^{\mathrm{b}}$ & $11.89 \pm 0.00^{\mathrm{b}}$ & $18.97 \pm 0.03^{b}$ & $22.59 \pm 0.21^{b}$ & $27.07 \pm 0.03^{\mathrm{b}}$ & $35.29 \pm 0.02^{\mathrm{bc}}$ \\
\hline 28 & NGR-JG-17-C & $9.08 \pm 0.00^{\mathrm{b}}$ & $11.63 \pm 0.01^{\mathrm{b}}$ & $21.49 \pm 0.04^{\mathrm{b}}$ & $22.94 \pm 0.01^{\mathrm{b}}$ & $31.17 \pm 0.05^{\mathrm{b}}$ & $34.81 \pm 0.01^{\mathrm{bc}}$ \\
\hline
\end{tabular}

Values are means \pm standard error, values followed by the same alphabet(s) in a column do not statistically differ at P $>0.05$ tested by Duncan Multiple Range Test. NST - Non stressed; ST - stressed. 


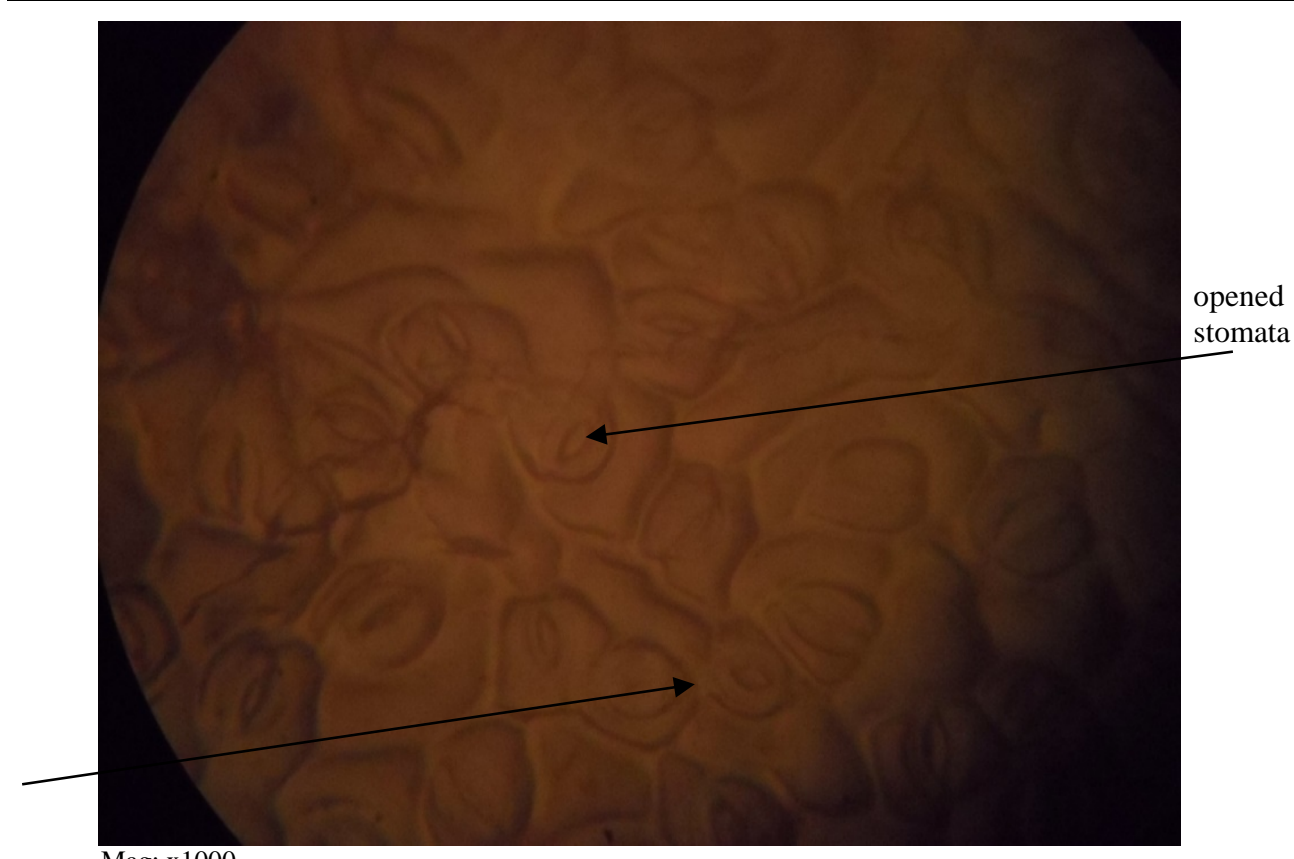

Mag: x1000

Figure 2. Stomata opening of Bambara Groundnut in non-stressed condition

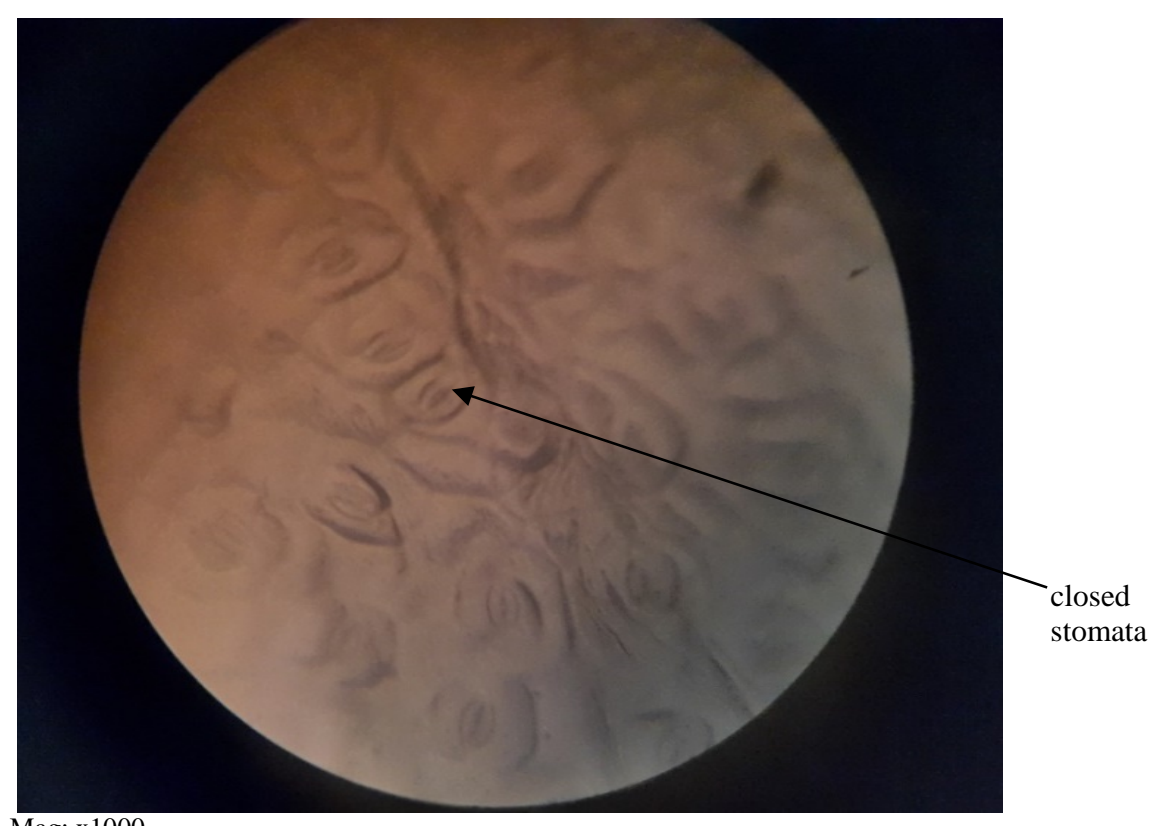

Mag: x1000

Figure 3. Stomata opening of Bambara Groundnut in stressed plant. 


\section{Discussion}

Relative water content is the amount of water present in the leaf tissues. The significant differences observed in the relative water content of the bambara groundnut accessions in both stressed and non-stressed plants is an indication of genetic variability in the accessions ability to either absorb water from the soil or to control water loss through the stomata. It was observed that accession NGB-01491 had the highest relative water content both in the stressed and non-water stressed condition while accession NGR-KG-02 had the lowest relative water content. For some of the accessions studied the relative water content was higher in the non-stressed plants and others were higher in the stressed plants. High relative water content under drought stressed conditions was observed in all the accessions which helped to maintain water balance. Higher relative water content in leaves has been reported as selection criteria to breed plants tolerant to drought stress [RAHAMAN \& al. 2000].

Assessment of pigment content has also become an effective means of monitoring plant growth and estimating photosynthetic productivity [CHEN \& al. 2007]. The high chlorophyll content observed in the bambara groundnut accessions both in the stressed and non-stressed plants although higher in the non-stressed plants is an indication that the chloroplast was not destroyed by the water stress. The values observed were lower than that observed by VURAYAI \& al. (2011) who recorded no significant differences in chlorophyll content between stressed and non-stressed plants suggesting that chlorophyll content in bambara groundnut landraces was not sensitive to water stress. FAROOQ \& al. (2009) reported that chlorophyll content decreased in water stressed plants. Similar reduction in chlorophyll content in water stressed plants has also been reported in barley [ANJUM \& al. 2003] and sunflower [KIANI \& al. 2007].

The closed stomata observed in the water stressed accessions is an indication that bambara groundnut landraces responded to drought through stomata closure (Figure 3). This helped to reduce transpiration loss which is a characteristic of drought avoidance and escape mechanism. Stomata closure has been previously reported by COLLINSON \& al. (1997) as a component of bambara groundnut drought resistance mechanism, however BLUM (2005) argued that stomata closure is a negative response to water stress in that it reduces carbon dioxide availability leading to yield reduction under water stress. Reduction in intracellular carbon dioxide, due to stomata closure resulted in reduced substrate availability for photosynthesis, hence leading to reduced yield in stressed plants.

\section{Acknowledgements}

The Authors wish to acknowledge and appreciate National Centre for Genetic Resources and Biotechnology, Ibadan and Agricultural Development Project Extension officers of Nigeria for providing some of the seeds used in the research.

\section{Notes on contributors}

Dorcas Ropo ABEJIDE is a plant breeder with special interest in the collection and evaluation of germplasm of underutilized crops. Her work focuses on the morphological, physiological and molecular evaluation of germplasm for high yield, disease resistance and drought tolerance.

Olamide Ahmed FALUSI is a professor of Applied Plant Genetics and Breeding in the Department of Plant Biology, School of Life Sciences, Federal University of Technology Minna, 
Nigeria. He is involved in research in three areas viz Cytogenetics, plant breeding and molecular Biology. Currently he is studying the germplasm of economic crops in Nigeria.

Andrew Saba GANA is a Professor of Plant Breeding and Genetics. He has worked on host Plant resistance in the areas of drought, African Rice gall midge and Iron toxicity. He has published about 80 papers in journals, book chapters in both National and International publications. He has also supervised several post graduate students.

Matthew Omoniyi ADEBOLA is an Associate Professor of Plant Pathology in the Department of Pant Biology, School of Life Sciences, and Federal University of Technology Minna, Nigeria. He is involved in researches on plant diseases caused by fungi.

Abdulhakeem ABUBAKAR is a Lecturer in the Department of Plant Biology, School of Life Sciences, Federal University of Technology Minna, Nigeria. His specialty is in Plant Genetics and Breeding. His research areas of interest are improvement of Tropical plants and plant fungi disease management.

Mohammed Chata DANGANA is a Lecturer in the Department of Plant Biology, School of Life Sciences, and Federal University of Technology Minna, Nigeria. His specialty is in Plant Genetics and Breeding. His research areas of interest are improvement of vegetable crops of the family Malvaceae notable among them are Abelmoschus esculentus, Hibiscus sabdariffa and Gossypium hirsutum.

\section{References}

ABEJIDE D. R., FALUSI O. A., GANA S. A., ADEBOLA M. O., DAUDU O. A. Y. \& SALIHU B. Z. 2018. Evaluation of seed yield of Nigerian Bambara groundnut landraces under varying water conditions. Notulae Scientia Biologicae. 10(2): 233-239. https://doi.org/10.15835/nsb10210238

ABEJIDE D. R., FALUSI O. A., GANA S. A., ADEBOLA M. O., MUHAMMAD L. M. \& GADO A. A. 2017. Evaluation of drought tolerance indices in Nigerian Bambara groundnut landraces. International Journal of Applied Biological Research. 8(2): 142-148.

ADU-DAPAAH H. K. \& SANGWAN R.S. 2004. Improving Bambara groundnut productivity using gamma irradiation and in vitro techniques. African Journal of Biotechnology. 3(5): 260-265. https://doi.org/10.5897/AJB2004.000-2048

ANJUM F., YASEEN M., RASUL E., WAHID A. \& ANNUM S. 2003. Water stress in Barley (Hordeum vulgare L.) effect on chemical composition and chlorophyll contents. Pakistan Journal of Agricultural Sciences. 40(2): 45-49.

AZAM-ALI S. N., SESAY A., KARIKARI S. K. \& MASSAWE F. J. 2001. Assessing the potential of an underutilized crop - a case study using bambara groundnut. Experimental Agriculture. 37(4): 433-472. https://doi.org/10.1017/S0014479701000412

BLUM A. 2005. Drought resistance, water-use efficiency and yield potential - are they compatible, dissonant or mutually exclusive? Australian Journal of Agricultural Research. 56: 1159-1168.

CHEN L., HUANG J. F., WANG F. M. \& TANGY. L. 2007. Comparison between back propagation neural network and regression models for the estimation of pigment content in rice leaves and panicles using hyperspectral data. International Journal of Remote Sensing. 28(6): 3457-3478. https://doi.org/10.1080/01431160601024242

COLLINSON S. T., CLAWSON E. J., AZAM-ALI S. N. \& BLACK C. R. 1997. Effects of soil moisture deficits on the water relations of bambara groundnut (Vigna subterranea). Journal of Experimental Botany. 48: 877-884. https://doi.org/10.1093/jxb/48(4):877

FAROOQ M., WAHID A., KOBAYASHI N., FUJIHA D. \& BASRA S. M. A. 2009. Plant Drought stress, effects, mechanisms and management. Agronomy Sustainable Development. 29: 185-212.

KIANI S. P., GRIEU P., MAURY P., HEWEZI T., GENTZBITTEL L. \& SARAFI A. 2007. Genetic Variability for physiological traits under drought conditions and differential expression of water stress-associated genes in sunflower (Helianthus annus L.). Theoretical and Applied Genetics. 114(2): 193-207. https://doi.org/10.1007/s00122-006-0419-7

LACROIX B., ASSOUMOU Y. \& SANGWAN R. S. 2003. Efficient in vitro direct shoot organogenesis and regeneration of fertile plants from embryo explants of Bambara groudnut (Vigna subterranea (L.) Verdc.). Plant Cell Reports. 21(12): 1153-1158. https://doi.org/10.1007/s00299-003-0647-0 


\section{EFFECT OF WATER STRESS ON PHYSIOLOGICAL PARAMETERS OF BAMBARA...}

LINNEMANN A. R. \& CRAUFURD P. Q. 1994. Effects of temperature and photoperiod on phenological development in three genotypes of bambara groundnut (Vigna subterranea). Annals of Botany. 74(6): 675-681.

MALHOTRA R. S. \& SAXENA M. C. 2002. Strategies for overcoming drought stress in Chickpea. I.C.A.R.D.A Caravan Issue No 17, December 2002.

PORRA R. J., THOMPSON W. A. \& KRIEDEIMANN P. E. 1989. Determination of accurate extinction coefficients and simultaneous equation for assaying chlorophylls a and b extracted with four different solvents: verification of the concentration of chlorophyll standards by atomic absorption spectroscopy. Biochemica et Biophysica Acta. 975: 384-394.

RAHMAN S., SHAHEEN M. S., RAHMAN T. \& MALIK T. A. 2000. Evaluation of excised leaf water loss and relative water content as screening techniques for breeding drought resistant wheat. Pakistan Journal of Biological Sciences. 3: 663-665. https://doi.org/10.3923/pjbs.2000.663.665

TURNER N. C. \& BEGG J. C. 1981. Pant water relations and adaptation to drought. Plant and Soil. 58: 97-113.

VURAYAI R., EMONGOR V. \& MOSEKI B. 2011. Physiological responses of Bambara groundnut (Vigna subterranea L. Verdc.) to short periods of water stress during different developmental stages. Asian Journal of Agricultural Sciences. 3(1): 37-43.

\section{How to cite this article:}

ABEJIDE D. R., FALUSI O. A., ADEBOLA M. O., GANA A. S., ABUBAKAR. A. \& DANGANA M. 2020. Effect of water stress on physiological parameters of bambara groundnut (Vigna subterranea (L.) Verdc.) accessions. J. Plant Develop. 27: 111-120. https://doi.org/10.33628/jpd.2020.27.1.111 